\title{
Application of Comparative Analysis to the Development Concepts of Socio-Economic Mesosubjects
}

\author{
Kuzmenko N.I.* \\ Voronezh State Pedagogical University \\ Voronezh, Russia \\ e-mail:diasku@mail.ru \\ Salikov Y.A. \\ Voronezh State University of Engineering Technologies \\ Voronezh, Russia \\ e-mail: saural@rambler.ru
}

\author{
Beilina A.F. \\ Voronezh State Pedagogical University \\ Voronezh, Russia \\ e-mail: abejlina@yandex.ru \\ Butova L.M. \\ Voronezh State Pedagogical University \\ Voronezh, Russia \\ e-mail: larbutova@yandex.ru
}

\author{
Bakalova T.V. \\ Voronezh State Pedagogical University \\ Voronezh, Russia \\ e-mail: barta2004@yandex.ru
}

\begin{abstract}
Nowadays much attention is paid to the identification of the features of socio-economic development of the territory. The concept of "territory" is multidimensional and includes a number of meaningful approaches. One of these offers the introduction of macro -, meso, and microsubjects based on the use of spatial boundaries. In this regard, the need to study the trends and conditions of spatial subjects' development is of great importance. Since currently the focus of studying the socioeconomic state and development of the territory is primarily on the meso and micro level, it is extremely important to systematize scientific concepts and methodological aspects related to the functioning and development of mesosubjects. The analysis of approaches to determining the content of such concepts as "territory", "space" and "region" has shown that these categories are closely interrelated with one another, but do not entirely reflect the entire contemporary set of peculiarities in mesosubjects development. Therefore, the authors explain the possibility of using the "regional spatial system" concept (RSS). The study performed on the basis of comparative analysis of concepts shows that the distinctive features of " RSS "in relation to other concepts are as follows: appearance of an additional production factor ("information"); intellectual nature of property; consistency of socio-economic relations manifestations, threats to economic and social security. The study of these conditions' manifestations will enable to perform a qualitative assessment of mesosubjects' socio-economic state. Thus, taking into account the characteristics of the regional spatial system it is possible to come to the following conclusion: to scientifically elaborate the strategic tasks of contemporary regional mesosubjects development it is necessary to perform qualitative assessment of "RSS" components.
\end{abstract}

Keywords - space, territory, region, regional spatial system, mesosubject.

\section{INTRODUCTION}

Nowadays professional scientific literature is updating discussion issues on the problems of spatial development of the country, fields, regional and territorial entities. At the same time, the dynamics of the society`s spatial organization demonstrates an increasingly stable tendency to differentiate territories according to various comparative criteria. The contemporary economy of the country is a complex multisubject, multi-dimensional, multi-level and multi-aspect complex, the stability of the functioning and development of which depends on many factors and conditions. In this regard, the researchers of spatial development of territorial entities need qualitative identification and comparative analysis of key scientific and practical categories that reflect the development features of socio-economic mesosubjects in complex and rapidly changing economic conditions.

Nowadays the issues of space hierarchical structure are actively discussed by representatives of various fields of expertise. In accordance with one of the most common approaches, spatial units are divided into megasubjects, macrosubjects, mesosubjects, microsubjects. The question of composition and content of socio-economic system hierarchical levels is one of the most debatable issues today. From the author's point of view, the structure of the socioeconomic system within territorial borders may include such levels as:

- «macro-subjects» - national state («national economy»);

- «mesosubjects»-regions;

- «microsubjects»-districts («municipalities»). 
In order to determine the condition and direction of socioeconomic mesosubjects development, it seems appropriate to conduct a comparative analysis of the content of several key terminological categories in order to identify their more accurate compliance with modern requirements and conditions. In the author's opinion, the multi-subject, multi-dimensional, multi-level and multi-aspect nature of the analyzed categories makes it necessary to apply the basic statements of the system approach in this study.

Creating a system theory of inter-level interactions is especially important in today's situation, when searching for effective regional policy options that can enhance the development of socio-economic mesosubjects and reduce negative factors that prevent this. Thus, this article offers a comparative approach in terms of taking into account the features of the hierarchical level structure of the socioeconomic system while simultaneously reflecting the systemwide characteristics.

The main ideas of the article consist in the proposed comparative analysis applied to the content of concepts. These concepts characterize the development peculiarities of socioeconomic mesosubjects, which can be summarized as follows:

1. The total of territorial entities at all levels forms the "subject core" of socio-economic relations, the stability of which determines, on the one hand, manageability, on the other-its ability to resist various threats;

2. The use of a systematic approach in changing economic conditions allows a multi-faceted approach to the concept of socio-economic mesosubjects development;

3. The categories "space", "territory", and" region" are considered from different points of view and by using various approaches, but their content characteristics are not sufficient to understand the complex modern socio-economic transformations of space. In this regard, on the basis of the system approach, the scientific category of "regional spatial system" (RSS) is proposed for use. The question of the sustainable socio-economic situation of the mesosubject comes down to the task of studying the development of "RPS" as the basis of spatial development.

4. Comparative analysis of concepts, reflecting the state and development of mesosubjects leads to understanding the conditions of transition from one definition to another and the finding the benefits of exploring mesosubjects as regional spatial systems that will allow determining the factors leading to socio-economic changes of mesosubjects and threats to the economic security of mesosubjects.

\section{DISCUSSION}

The authors consider the opinions provided by experts of the definition framework - they are "space", "territory", "region". Generalization of such judgments presented in the literature allows coming to the conclusion that the category of "space" is used primarily by regional studies. However, this category has the right to be used in other areas, since it is usually used to describe any logically conceivable structure or form that can serve as a medium for the implementation of certain structures or operations. The essence of space is considered by many authors from different fields of knowledge. Taking into account a variety of opinions, we can generally assess three directions where the concepts of "space", "territory" and "region" are most often applied physical and geographical, administrative and legal and economic areas.

In the geographical sciences, such a concept as geographical space is applied. In a broad sense, the authors consider it as part of the Earth's surface (land, territory), which has its own characteristics. E.B. Alaev understands geographical space as "an objective universal and cognitive form of existence of material geographical formations and objects within the geoversum" [1]. The geographical encyclopedia treats geographical space as "a form of geographical objects and phenomena of existence within a geographical coat; a set of relations between geographical objects located on a specific territory and developing over time" [3].

Taking into account the administrative and legal approach, researchers use the definition of "legal space". Thus, S.N. Baburin defines a unified legal space as one of the material and legal mechanisms for ensuring the stability of the legal mode of the state's territory, without considering it as an independent legal category" [2]. The unity of the legal space, according to S. Somov, is "a state of consistency, correlativity and subordination of legal norms due to the Federal Constitution, based on their legal significance (Verity)" [11]. These interpretations and opinions of other authors provide reasons for saying that the legal space is a certain area that has the legal rules of the state.

As for the economic approach, the concept of space is not new to the economic thought. This problem was also dealt with by J. Stewart, A. Smith, D. Ricardo and others. In the evolutionary perspective, the definition of "economic space" is used in relation to territorial development (Table. 1). That serves as an objective basis for the socio-economic development of the region and the formation of an effective management paradigm.

The data in Table 1 prove that starting from the theory of productive forces distribution, the evolution of economic space approaches has been supplemented by the structure, hierarchy, differentiation of economic space and the tendency for concentration, agglomeration, and polarization.

The definition of "territory" is also widely used in science. Let us consider the content of "territory" from three points of view: 1. physical geographical, 2. legal and 3. economic. G.M. Lappo notes that "territory is" an amazing phenomenon characterized by extreme versatility. It is an integral part of human activity, a complex socio-economic organism, a multilayered historical and cultural formation, an embodiment of the arts synthesis and a stage for significant events" [7].

Summarizing the opinions of these and other experts in geographical science and practice, we conclude that "territory" is considered as a part of space, which, in contrast to the water area (a limited part of the water surface of the Earth) and aerotorium (part of the air shell of the Earth), corresponds to 
the solid surface of the Earth. Legal scholars consider a territory as a certain space that is separated from other spaces. However, unlike geographers, the latter indicate a certain legal status and a corresponding legal mode as characteristics of the territory.

In the economic sphere, the territory is represented taking into account the criteria specified in Federal Law No. 131-FZ of October 6, 2003 "On General Principles of Local Autonomy in the Russian Federation" [6]. This normative act, in particular, states that local autonomy is carried out within the territory "distinguished by its socio-economic integrity, the presence of industrial and social infrastructure necessary to ensure the living conditions of the population" (Federal Law No. 131-FZ of October 6, 2003 "On General Principles of Local Autonomy in the Russian Federation").
The concept of «region» similarly to the categories discussed above can be presented from the same three points of view. In the context of the physical and geographical approach, the region is a territorial unit that has geographical boundaries and certain characteristics. Many authors share a similar opinion (E.B. Alaev, N.N. Nekrasov, V.G. Ignatov, B.A. Raizberg etc.). Here are some of them. N.N. Nekrasov believes that "the region is a large territory of a country with approximately the same environmental conditions, and, what is important, with a specific focus of productive forces development, which is based on a combination of natural resources and the corresponding social tissue" [8]. A.E. Alaev understands the region as "a localized territory that has unity, interconnectedness of constituent elements, and integrity" [1].

TABLE I. MAJOR APPROACHES TO CONSIDERING "SPACE" CATEGORY IN THE REgIONAL ECONOMY

\begin{tabular}{|c|c|c|c|}
\hline Time Span & Author & Concepts & $\begin{array}{l}\text { Generalization and Significance } \\
\text { for Scientific and Practical Foundation }\end{array}$ \\
\hline \multicolumn{4}{|c|}{ International Approaches } \\
\hline \multirow{2}{*}{$\begin{array}{l}\text { XII-XIII } \\
\text { centuries }\end{array}$} & A. Smith & The concept of absolute advantages & \multirow{2}{*}{$\begin{array}{l}\text { Explaining advantages of productive forces } \\
\text { distribution and on the territory }\end{array}$} \\
\hline & D. Ricardo & The theory of comparative advantages & \\
\hline \multirow{6}{*}{$\begin{array}{l}\text { XIX-XX } \\
\text { centuries }\end{array}$} & F. Ratzel & Seven laws of spatial growth of the state & \multirow{6}{*}{$\begin{array}{l}\text { Introducing the concept of «economic } \\
\text { space». Selecting the determining factor that } \\
\text { is transport costs }\end{array}$} \\
\hline & J.H. von Thünen & $\begin{array}{l}\text { A study on the effect of grain prices, the richness of the soil and } \\
\text { overhead costs on agriculture, describing the factors of agricultural } \\
\text { production placement }\end{array}$ & \\
\hline & Weber & $\begin{array}{l}\text { Spatial industry distribution (optimal) is determined by three «aspects»: } \\
\text { transport, labor, and agglomeration }\end{array}$ & \\
\hline & W. Christaller & $\begin{array}{l}\text { Theory of "Central places", which explains the thesis about the } \\
\text { hierarchical structure of economic space }\end{array}$ & \\
\hline & W. Isard & $\begin{array}{l}\text { The category of economic space is constituted by a system of relations: } \\
\text { industrial and interterritorial ones }\end{array}$ & \\
\hline & A. Lösch & Concept of spatial economic equilibrium & \\
\hline \multirow[t]{3}{*}{ XX century } & $\begin{array}{l}\text { M. Streit } \\
\text { K.Richter } \\
\text { S. Tsamanski }\end{array}$ & Theories of industrial complexes & \multirow[t]{3}{*}{$\begin{array}{l}\text { Considering the region as a complex system } \\
\text { with economic and technological structures }\end{array}$} \\
\hline & M. Porter & Theory of spatial industrial clusters & \\
\hline & $\begin{array}{l}\text { M. Enright } \\
\text { S. Goetz }\end{array}$ & Connection of the regional space with the network economy & \\
\hline \multirow[t]{2}{*}{$\begin{array}{l}\text { XX-XXI } \\
\text { centuries }\end{array}$} & $\begin{array}{l}\text { C. Carlson } \\
\text { V. Tsan }\end{array}$ & $\begin{array}{l}\text { Connection of the economic space structure with human capital and } \\
\text { regional division of labor }\end{array}$ & \multirow[t]{2}{*}{$\begin{array}{l}\text { Importance of network organization in the } \\
\text { region's economy }\end{array}$} \\
\hline & $\begin{array}{l}\text { R. Schuler } \\
\text { P. Capello }\end{array}$ & The concept of a "network" economy & \\
\hline \multicolumn{4}{|c|}{ Russian Approaches } \\
\hline \multirow[t]{3}{*}{$\mathrm{XX}$ century } & N.N. Baransky & $\begin{array}{l}\text { The question of geographical division of labor as "a spatial form of } \\
\text { social division of labor characterized by a gap between the place of } \\
\text { production and the place of consumption". }\end{array}$ & \multirow{3}{*}{$\begin{array}{l}\text { Explaining the formation and specialization } \\
\text { of economic districts and the allocation of } \\
\text { methods for planning territorial } \\
\text { development. Applying economic and } \\
\text { mathematical methods to validate territorial } \\
\text { development }\end{array}$} \\
\hline & $\begin{array}{l}\text { V.S. Nemchinov Y.G. } \\
\text { Saushkin }\end{array}$ & $\begin{array}{l}\text { Balance method of economic development. Formation of territorial- } \\
\text { industrial (regional) complexes }\end{array}$ & \\
\hline & $\begin{array}{l}\text { A. E. Probst } \\
\text { R.I. Shniper } \\
\text { A.G. Granberg }\end{array}$ & $\begin{array}{l}\text { Analysis of the national economy as a system of regions interacting in } \\
\text { the market environment with state regulation of market mechanisms. } \\
\text { The analysis methodology is based on the concepts of resource and } \\
\text { technological potential of regional development, achievable effective } \\
\text { conditions and the core of multi-regional systems, and spatial economic } \\
\text { equilibrium }\end{array}$ & \\
\hline $\begin{array}{l}\mathrm{XX}-\mathrm{XXI} \\
\text { centuries }\end{array}$ & A.G. Aganbegyan & Scientific approaches to planning and organizing production & $\begin{array}{l}\text { Improving production efficiency, analyzing } \\
\text { the rational allocation of productive forces }\end{array}$ \\
\hline
\end{tabular}

The administrative and legal approach is fully represented in the works of Y.A. Korchagin, Y.N. Gladkiy, G.V. Gutman, A.I. Chistobaev, V.N. Leksin and others. G.V. Gutman notes that "a region is a territorial entity that has clearly defined administrative borders, within which the reproduction of social and economic processes that ensure the population functioning is carried out, due to the region's place in the system of social division of labor" [4]. Thus, from the point of view of the above-mentioned approach, a region is defined as a territory within the administrative boundaries of an object.

A number of authors (I.V. Dobrynin, M.V. Stepanov, I.N. Shapkin etc.) consider the region from the economic point of view. In their explanations, the region is represented as a territory of 
human activity, which is characterized by industrial specialization. This is confirmed by the words of A.I. Dobrynin that "the region is a special-purpose territorial part of the country`s national economy, characterized by unity and integrity of the reproduction process" [5]. However, we believe that the use of these concepts is not sufficient in contemporary research. From the above-described statements it is easy to grasp that they lack features of complex modern socio-economic transformations of space and threats to socio-economic development. Taking into account what has been identified, it is necessary to introduce a new category - "regional spatial system", which is based on a systematic approach.

By this time experts have not paid due attention to the description and content of "regional spatial system" concept. Taking into account fundamental statements of the system approach, we can define "regional spatial system" as a locating a set of interrelated elements and their best combination in a certain territory, as well as the presence of factors that lead to socio-economic transformations, in particular, provoking threats to the economic security of the territory."

Thus, "space" includes the concepts of "territory", "region", and "regional spatial system". However, according to the content, one or another notion is mainly used (Fig. 1).

Considering the evolutionary characteristics of opinions by domestic and foreign authors and taking into account the current transformations in the spatial organization of mesosubjects, we can come to the conclusion that sentence of "space" is a key category, including a set of concepts, which differ by the manifestation character. This is evidenced by the comparative data in Figure 1, emphasizing the fact that in the current trends of territorial development it is impossible to consider space without taking into account the manifestations of institutional and economic nature, which act as the basic characteristics of the regional spatial system.

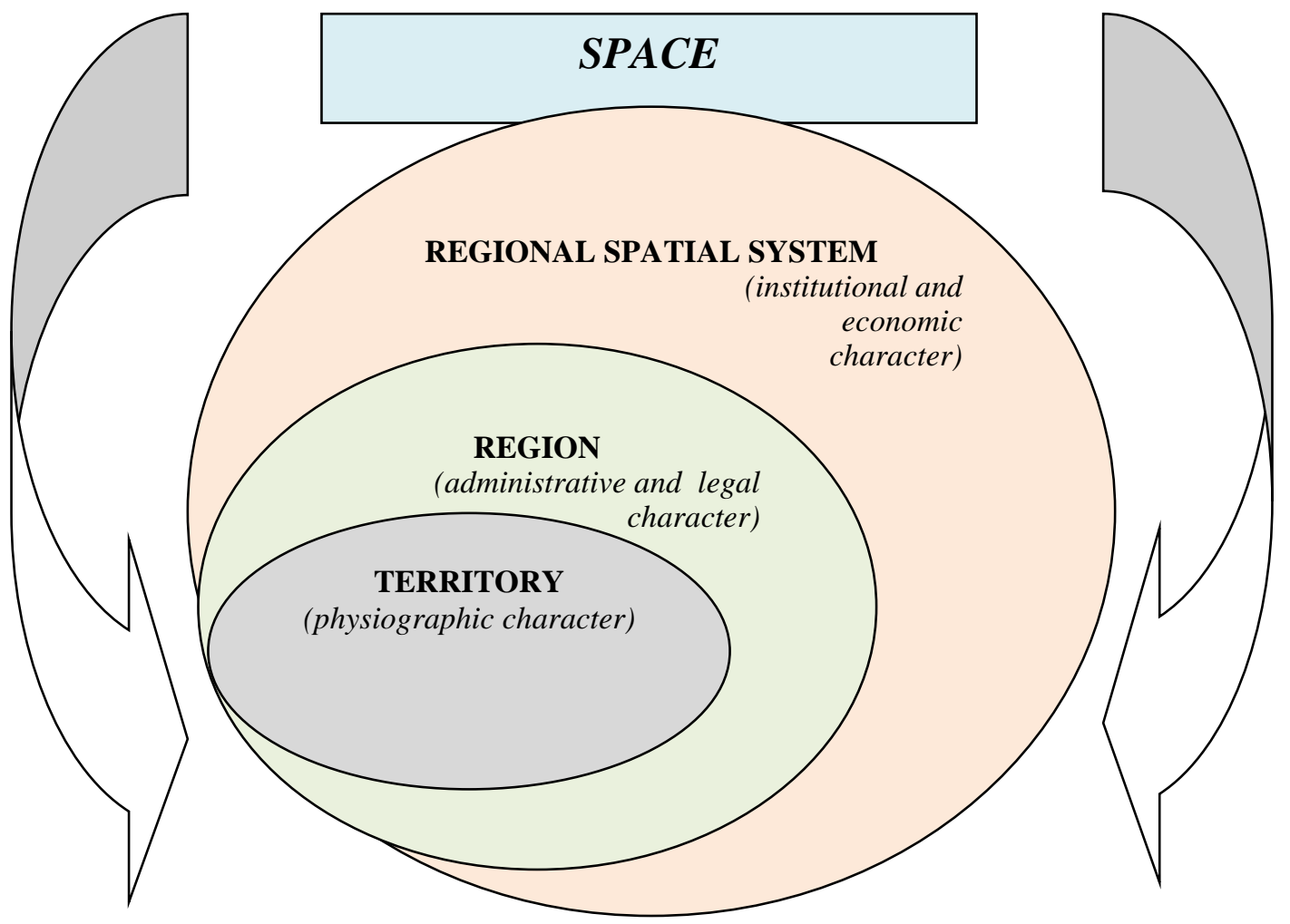

Fig. 1. Components of the "Space" Category» 
TABLE II. COMPARATIVE ANALYSIS OF THE EXPLORED NOTIONS

\begin{tabular}{|c|c|c|c|c|}
\hline \multirow{2}{*}{ Characteristic } & \multicolumn{4}{|c|}{ Notions to be Compared } \\
\hline & Space & Territory & Region & Regional Spatial System (RSS) \\
\hline $\begin{array}{l}\text { Etymological nature } \\
\text { of the concept (field } \\
\text { of use) }\end{array}$ & $\begin{array}{l}\text { physical and } \\
\text { geographical } \\
\text { character }\end{array}$ & $\begin{array}{l}\text { physical and geographical } \\
\text { character }\end{array}$ & administrative and legal nature & institutional and economic character \\
\hline $\begin{array}{l}\text { Synonymous row } \\
\text { (meaning) }\end{array}$ & $\begin{array}{l}\text { 1. part of the Earth's } \\
\text { surface; } \\
\text { 2. a certain section } \\
\text { that has legal } \\
\text { regimes of the state }\end{array}$ & $\begin{array}{l}\text { 1. land space (with borders); } \\
\text { 2. part of the land surface }\end{array}$ & $\begin{array}{l}\text { 1. section separated from other } \\
\text { sections; } \\
\text { 2. a large area (region) that } \\
\text { includes a group of related } \\
\text { entities; } \\
\text { 3. territorial unit of the state }\end{array}$ & $\begin{array}{l}\text { locating a set of interrelated elements } \\
\text { and their best combination in a certain } \\
\text { territory, as well as the presence of } \\
\text { factors that lead to socio-economic } \\
\text { transformations in particular, } \\
\text { provoking threats to the economic } \\
\text { security of the territory» }\end{array}$ \\
\hline $\begin{array}{l}\text { Aims of using the } \\
\text { concept }\end{array}$ & $\begin{array}{l}\text { to reflect the } \\
\text { production factor of } \\
\text { "land" as fully as } \\
\text { possible }\end{array}$ & $\begin{array}{l}\text { to reflect the production factor of } \\
\text { "land" as fully as possible and to } \\
\text { indirectly reflect "capital" }\end{array}$ & $\begin{array}{l}\text { to reflect the production factors } \\
\text { of "labor", "capital" and } \\
\text { "resources " as fully as possible }\end{array}$ & $\begin{array}{l}\text { to reflect the production factors of } \\
\text { "knowledge", "human resources" and } \\
\text { "security" as fully as possible }\end{array}$ \\
\hline $\begin{array}{l}\text { Subject (character) } \\
\text { of development }\end{array}$ & increase in size & $\begin{array}{l}\text { improvement of spatial } \\
\text { characteristics }\end{array}$ & $\begin{array}{l}\text { solving socio-economic and } \\
\text { ecological problems (of the } \\
\text { population) }\end{array}$ & $\begin{array}{l}\text { development of productive forces and } \\
\text { social processes based on } \\
\text { administrative and economic methods } \\
\text { and solutions }\end{array}$ \\
\hline $\begin{array}{l}\text { Ways to solve } \\
\text { development } \\
\text { problems }\end{array}$ & $\begin{array}{l}\text { increase in size, } \\
\text { acquisition }\end{array}$ & expansion of borders & $\begin{array}{l}\text { increasing the significance and } \\
\text { level regarding neighboring } \\
\text { regions through rearrangement, } \\
\text { reforms and innovation }\end{array}$ & $\begin{array}{l}\text { cooperation of all necessary resources } \\
\text { based on their most rational } \\
\text { combination (resource synergy) }\end{array}$ \\
\hline $\begin{array}{l}\text { Needs (and ways to } \\
\text { meet them) }\end{array}$ & $\begin{array}{l}\text { environmental } \\
\text { factors, territory }\end{array}$ & $\begin{array}{l}\text { communication and technological } \\
\text { factors (communication, } \\
\text { transport, accessibility, agro- } \\
\text { climatic conditions) }\end{array}$ & $\begin{array}{l}\text { progress, recognition (respect). } \\
\text { Achieving certain target } \\
\text { orientations by solving tactical } \\
\text { and strategic tasks }\end{array}$ & $\begin{array}{l}\text { self-realization and self-development, } \\
\text { ensuring the security of development } \\
\text { (programs and projects of federal } \\
\text { significance) }\end{array}$ \\
\hline $\begin{array}{l}\text { Transition, transfer } \\
\text { of object ownership }\end{array}$ & $\begin{array}{l}\text { possible transfer of } \\
\text { technical property }\end{array}$ & $\begin{array}{l}\text { possible transfer of economic } \\
\text { property }\end{array}$ & $\begin{array}{l}\text { possible legal option for } \\
\text { changing proprietor }\end{array}$ & $\begin{array}{l}\text { intellectual property due to economic } \\
\text { conditions and legal norms }\end{array}$ \\
\hline $\begin{array}{l}\text { Manifesting } \\
\text { innovation }\end{array}$ & practically absent & use of innovations & $\begin{array}{l}\text { use of innovations, innovations } \\
\text { in human capital }\end{array}$ & $\begin{array}{l}\text { use of innovations and their } \\
\text { manifestation in implementing } \\
\text { economic security programs }\end{array}$ \\
\hline
\end{tabular}

\section{METHODS AND MATERIALS}

Taking into account the findings of this study, a comparative analysis of "space", "territory", "region", and "regional spatial system" concepts was performed with the corresponding justification for the need to allocate the category of "RSS" (Table 2) in order to ensure sustainable socio-economic development of mesosubjects.

Data provided by Table 2 help to identify a number of distinguishable characteristics of "RSS" in relation to other categories. First of all, they are as follows: presence of interrelated elements: availability of investment, human capital formation, rationality of production, and increasing importance of intangible assets, use of economic security, without which it will be difficult to ensure the development of metasubjects in the future. To strengthen the statements of the conducted comparative analysis let us formulate the conditions for the transition from one category state to another (Fig. 2).

The "RSS" conditions indicated in Figure 2 differ significantly from the "space", "territory", and "region" statements and confirm the above-mentioned arguments supporting the need to introduce the "RSS" category and the application of its statements in ensuring the socio-economic development of mesosubjects.

Thus, in the current economic conditions, it is important to use the "RSS", since in contrast to other categories considered, this model assumes the presence and consideration of factors that lead to socio-economic transformations. Specific ones prove to be threats to economic security and threats to social security.

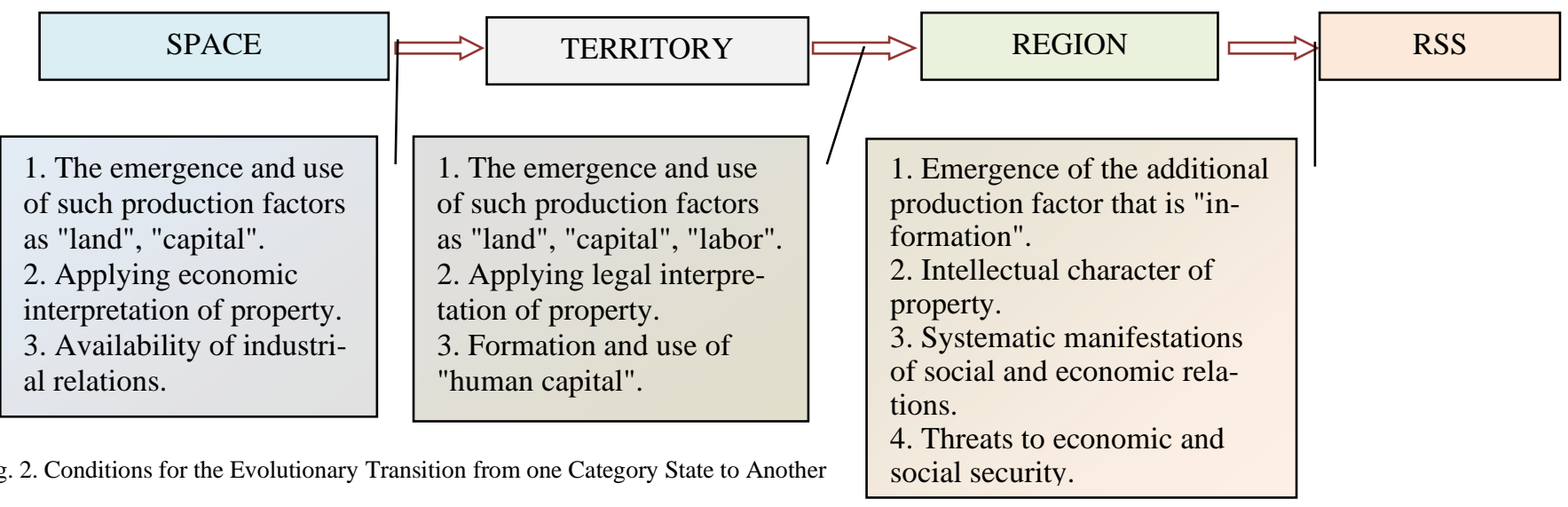




\section{CONCLUSION}

The peculiarities of regional spatial systems functioning determined the study of methodological and practical research in the field of regional development. In the contemporary developing economy of mesosubjects, the effective state of the regional spatial system plays a significant role. For explaining the importance of using "RSS" in order to identify the features of socio-economic development of mesosubjects, a comparative analysis of "space", "territory", and "region" concepts was required. The generalized record of scientific research in the field of forming the content of these concepts has shown that there is currently a divergence of opinions among experts.

The results of the study show that the category "space" can be considered as the basis for other definitions, i.e. the space can include the territory, region, and "RSS". While exploring the definitions, it was revealed that the use of the term "territory" is primarily physical and geographical in nature. With the development of the society and the improvement of socio-economic relations, the administrative and legal character is starting to play an increasingly important role. This administrative and legal character is most actively manifested in relation to the "region" definition.

In the course of the society`s development, differentiation of territorial development has been manifested, and there is a need to study this situation in order to level it and identify threats to territorial development [9]. These problems must be considered with a systematic approach, taking into account not only the territory of the region, but also the institutional nature of its development, self-development, and security. In this context, it is appropriate to put forward the concept of "regional spatial system".

The author's concept on the formation and promotion of the "regional spatial system" concept will allow exploring the sustainable development of mesosubjects through "RSS" characteristics and conditions. In the future they will enable the assessment of the potential and directions of structural development. At the same time, manifestation of institutional and economic aspects is becoming more noticeable.

It is proved that a necessary condition for the effective functioning of mesosubject's regional spatial system is an intellectual form of structuring, which is able to balance existing structural proportions on the basis of enhancing economic and investment activity, on the one hand, identifying and preventing threats to socio-economic security, on the other hand.
The results show that further research in the analyzed area should be related to the detection of significant features in the complex process of regional spatial systems development, the creation of appropriate mechanisms for managing the development of economic entities, as well as to the active use of mathematical tools to describe the specific features of their development process.

The degree of "RSS" influence on the development of mesosubjects confirms the authors' conclusions concerning the need for quality integration evaluation of changing "RSS" components and conditions. This is to be done in order to explain factors leading to socio-economic changes in mesosubjects and to identify threats to economic security and define measures to reduce them.

Thus, the practical value of the article consists in potential using the features of the "RSS" by state and public authorities in the elaboration of strategies and programs for socioeconomic regions development, justification of forms and methods of state policy at the regional level, development of investment projects and programs for shaping the innovative landscape and socio-economic development of economic mesosubjects.

\section{References}

[1] E.B. Alaev, Socio-economic geography; conceptual and terminological dictionary. Moscow: Thought, 1983, pp. 98-99.

[2] S.N. Baburin, The territory of the state. Moscow, 1998, pp. 141-142.

[3] Encyclopedic Geographic Dictionary: concepts and terms, Chap. ed. A.F. Treshnikov. Moscow: Soviet Encyclop., 1988, pp. 100-101.

[4] G.V. Gutman, A.A. Miroedov, S.V. Fedin, Management of the regional economy. Moscow: Finance and statistics, 2002, p. 141.

[5] A.I. Dobrynin, Regional proportions of reproduction, Leningrad: Leningrad Publ. House, University University, 1977, p. 9.

[6] N.I. Kuzmenko, "Innovative activity of organizations as the basis for the formation of an innovative economy in the regions of the Russian Federation", Bull. of the Voronezh State Univer. of Engineer. Technol., vol. 79, no. (3)73, pp. 286-293, 2017.

[7] G.M. Lappo, Cities of Russia. The view of a geographer. Moscow: New Chronograph, 2012, pp. 126-127.

[8] N.N. Nekrasov, Regional economy, Theory. Problems, Methods. Moscow: Economics, 1978, p. 29

[9] Yu.A. Salikov, S.V. Vandysheva, L.V. Smarchkova, E.A. Chudakova, "Using the cluster approach in the development of industry in the region", Bull. of the Voronezh State Univer. of Engineer. Technol., vol. 80, no. 4, pp. 493-498, 2018.

[10] T.I. Ochinnikova, Yu.A. Salikov, V.V. Grigoryeva, Yu.N. Duvanova L.N. Tchaikovskaya, "Agglomeration effect in the development of economic security”, VGUIT Bull., vol. 2, no. 76, pp. 388-397, 2018.

[11] S. Somov, "Unity of Legal Space”, Legality, no. 2, p. 30, 2001. 